A N N A L E S

UNIVERSITATIS MARIAE CURIE-SKŁODOWSKA

LUBLIN - POLONIA

VOL. XXXII, 4

SECTIO J

2019

Uniwersytet Rzeszowski. Wydział Pedagogiczny

WALDEMAR FURMANEK

ORCID: 0000-0002-1032-4266

furmanek@ur.edu.pl

\title{
Podstawowe przyczyny zagubienia polskiej pedagogiki. Część 1
}

Basic Reasons of Losing Polish Pedagogy. Part 1

\section{STRESZCZENIE}

Pedagodzy polscy wydają się być zagubieni w precyzyjnym formułowaniu własnej problematyki badań. Przyczyn jest wiele. Najważniejsze to: błąd antropologiczny, duża dynamika przemian cywilizacyjnych, trudności z interpretacją i rozumieniem zjawisk współczesnej cywilizacji wiedzy, nowe oczekiwania wobec edukacji, konieczność reorientacji metodologii badań. Autor zwrócił uwagę na trudności z identyfikacją i rozumieniem kierunków przemian cywilizacyjnych, ich dynamiki, kompleksowości oraz ich nowej jakości. W artykule wskazano również na najważniejsze obszary badań, które pilnie wymagają penetracji przez współczesnych pedagogów.

Słowa kluczowe: zagubienie; cywilizacja; społeczeństwo wiedzy; edukacja

\section{WPROWADZENIE}

Postęp naukowo-techniczny generuje nowe dające się wykorzystać wyniki, lecz także stwarza rozliczne trudności czy problemy. Te zaś najwyraźniej uwidaczniają się w sytuacjach trudnych, jakie uzewnętrznia aktywność człowieka w wielorakich formach podejmowanej przez niego działalności. Chce on bowiem zmieniać jakość swojego życia, dąży do osobistego szczęścia i zarazem do zmiany swojego świata (środowiska swojego życia), poza tym chce zmienić samego siebie, przy czym często napotyka na: a) bariery poznawcze i emocjonalne, związane $\mathrm{z}$ trudnościami w uchwyceniu najważniejszych zjawisk zmianotwórczych, b) bariery psychofizyczne, utrudniające adaptację człowieka do szybkich zmian cywilizacyjnych i koniecznych ciągłych wyborów, c) trudności z radzeniem so- 
bie z psychologicznymi konsekwencjami tych przeobrażeń (Furmanek, 2015). Można przyjąć, że kompetencje człowieka w pokonywaniu trudności związanych z tymi barierami są wskaźnikami dysfunkcjonalności rozwiązań edukacyjnych występujących w polskich szkołach.

Współcześnie obserwujemy, doświadczamy i opisujemy znamiona zagubienia polskiej pedagogiki, czy raczej zagubienia polskich pedagogów. Dotyczy to też niejednoznaczności w formułowaniu misji nauk pedagogicznych. Ważną przyczyną podjętego w niniejszym opracowaniu zagadnienia są trudności z identyfikacją i zrozumieniem kierunków przemian cywilizacyjnych. Ich dynamika, kompleksowość i nowa niespotykana jakość zaskakuje także tych badaczy, którzy tej problematyce poświęcają więcej uwagi. Podstawą odnalezienia się w zmieniającej się rzeczywistości jest dostrzeganie, identyfikowanie, nazywanie i opisywanie najważniejszych zjawisk, dążąc do ich zrozumienia. „Opisujemy świat, by go zrozumieć i przewidywać, wyjaśniamy i przewidujemy, by w nim skutecznie działać" (Such, 1973, s. 17).

\section{TAJEMNICA CZŁOWIEKA ŹRÓDŁEM ZAGUBIENIA W PEDAGOGICE}

Wyniki nowych badań naukowych, wciąż bardzo liczne i szybko dostępne, często stawiają badaczy w sytuacji budzącej zadziwienie, zdumienie czy niedowierzanie. Dynamika przemian cywilizacyjnych jest tak duża, że piętrzą się trudności z wyjaśnianiem doświadczanych zjawisk. Opinia ta w pełni dotyczy podstawowego obiektu badań nauk pedagogicznych, którym jest człowiek. Pomimo intensywnych badan prowadzonych przez rozmaite dyscypliny naukowe człowiek pozostaje dla badaczy ciągłą tajemnicą, co bez wątpienia rzutuje na całość problematyki badań współczesnej pedagogiki (Furmanek, 2019).

Wychowanie i edukacja to podstawowe sprawy człowieka w świecie, środowisku jego życia, rozwoju i pracy. W przypadku nauk pedagogicznych, które mają zaproponować skuteczne działania wspomagające rozwój człowieka, sytuacja jest szczególnie trudna (Furmanek, 2014a). Na ogół, mocą tradycji filozoficznej sięgającej czasów starożytnych, człowiek postrzegany jest jako istota cielesno-duchowa (animal rationale według Boecjusza, „trzcina myśląca” według Blaise'a Pascala, ,istota zakorzeniona jedną nogą w naturze, drugą w kulturze” według Ericha Fromma) (por. Maryniarczyk, Stępień, 2003). Pomimo zróżnicowanej natury człowiek żyje i działa jako jedność, niepodzielna całość, a wszelkie próby redukcjonizmu stosowane w badaniach empirycznych sprawiają, że zdobyta na ich podstawie wiedza jest dalece niesatysfakcjonująca.

Przyjęty - także w postaci przedzałożenia, nie zawsze werbalizowanego - model człowieka decyduje o dalszych wyborach problematyki badań pedagogicznych i ukierunkowaniu metodologii ich badań (Furmanek, 2019). Jakże często jednak pedagodzy odwołują się do modelu, który jest podstawą tzw. błędu antropologicznego. 
Mówiąc inaczej, jest to błędna wizja człowieka, nie do końca spójna i scalona, która jest rozsiewana w kulturze, moralności, mentalności medialnej, a także w różnych sferach wychowania oraz budowaniu motywacji zachowań ludzkich (Furmanek, 2014a).

\section{DYNAMIZM PRZEMIAN CYWILIZACYJNYCH ŹRÓDŁEM ZAGUBIENIA W PEDAGOGICE}

Początek XXI w. cechuje się dynamiką nieustannych przemian, wielkich wydarzeń i przyspieszonego tempa życia człowieka. Książka Alvina Tofflera Szok przyszłości (2007) wskazuje, że dynamiczny rozwój nauki może spowodować sytuacje, w których nieprzygotowane społeczeństwo stanie wobec trudnych wyborów intelektualnych i moralnych. Aby złagodzić to „porażenie przyszłością”, należy się zastanowić nad strategią przetrwania jednostki, mikrośrodowisk i całego społeczeństwa.

Żyjemy w czasach gwałtownych przemian cywilizacyjnych. Odchodzi się od modelu życia społecznego ukształtowanego zjawiskami cywilizacji przemysłowej. Pojawia się z całą siłą nowa rzeczywistość, określana mianem cywilizacji informacyjnej. Na horyzoncie przemian, w obrębie cywilizacji informacyjnej, jawi się już kolejna, odmienna od dotychczasowej, nowa rzeczywistość - inna od tej już nieco poznanej, obecnie doświadczana. W związku z tymi przemianami w Polsce doświadczamy skutków jednoczesnej transformacji ustrojowej, społecznej, ekonomicznej, świadomościowej i aksjologicznej. W pracy Janusza Czapińskiego i Bogdana Wojciszke znajdujemy bardzo interesującą charakterystykę zmian zachodzących w Polsce:

PRL - jak ktoś trafnie zauważył - była basenem bez wody. Człowiek sobie nie popływał, ale też się i nie utopił.

W 1989 roku zaczęto ten basen napełniać, i to w tempie fali powodziowej. Wówczas okazało się, kto umie, a kto nie umie pływać, kto ma jeszcze szansę się nauczyć, a kto się utopi. Ta przemożna umiejętność pływania to syndrom cech ułatwiających przystosowanie się do radykalnie zmienionych reguł życia w III RP. Najistotniejszym jego elementem jest przedsiębiorczość - potocznie - spryt i zmysł ekonomiczny.

Test wodny ujawnił z całą brutalnością, jak bardzo nie jesteśmy pod tym względem równi. Część z nas - nazywana tutaj „lisami” - dysponuje bogatym repertuarem odpowiedzi na wyzwania i zagrożenia, czuje się w nowej rzeczywistości u siebie, akceptuje przekształcenia własnościowe i zasady gry wolnorynkowej (...), grupa ,jeży”, dysponujących jedną tylko odpowiedzią na wszelkie niebezpieczeństwa - zwinięciem się w kłębek - to przede wszystkim ludzie starsi lub źle wykształceni. Próbują przeczekać nowe porządki, tęsknią za rajem utraconego pustego basenu PRL... (Czapiński, Wojciszke, 1997, s. 37)

Jak zauważył Zygmunt Bauman (1997, s. 33): „Ludzkość jest w permanentnym szoku przyszłości”. Obecnie żyjemy w świecie narastających zmian do tego 
stopnia, że każde pokolenie żyje w nieco innej rzeczywistości społeczno-kulturowej, technicznej i cywilizacyjnej. Zmiana to nieunikniony ruch dotyczący komponentów struktury i relacji, jakie w niej występują. Człowiek powinien ją poznać, zrozumieć, być może zaakceptować, podjąć się jej przekształcenia i nauczyć się żyć w ciągle zmieniającym się świecie (Myoo, Hańderek, 2014).

Zmiana jest procesem, podczas którego jednostki zmieniają sposoby swego myślenia i postępowania. Piotr Sztompka (2009, s. 437-438) ujmuje zmianę jako „różnicę między stanem w jednym momencie czasu a stanem tego samego myślenia czy działania w innym momencie czasu". Te różnice stają się coraz bardziej znaczące dla jakości życia każdego człowieka.

Przede wszystkim warto uzmysłowić sobie, że cała rzeczywistość, chociaż jest jedna, nie ma charakteru jednorodnego - jest złożona i jakościowo zróżnicowana. Wielowymiarowość rozpoznawana jest najczęściej (lecz nie tylko) w odniesieniu do człowieka. Niezależnie od tego, jak będziemy uzasadniać owe przemiany, rzeczą fundamentalną jest to, że czasy współczesne charakteryzują się nową jakością życia i pracy człowieka. Rodzi to trudne do zdefiniowania wyzwania dla pedagogiki. Korzystanie z nowych możliwości cywilizacyjnych - stanowiących w istocie owoce tej współczesnej cywilizacji - wymaga nowej jakości człowieka.

\section{KIERUNKI PRZEMIAN CYWILIZACJI. OD RZEMIOSŁA DO NOWEJ REWOLUCJI PRZEMYSŁOWEJ}

Szkoła jest owocem swego czasu. Każdy etap rozwoju cywilizacji generuje określony model społeczeństwa. Dynamika przemian tego modelu pozostaje w koneksji z dynamiką przemian cywilizacji.

Jak zauważa Waldemar Furmanek (2017, 2018a), pierwsza rewolucja przemysłowa (koniec XVIII w. - pierwsza połowa XIX w.) dotyczyła przejścia od produkcji rzemieślniczej i manufakturowej do zmechanizowanej produkcji fabrycznej dzięki intensywnemu wykorzystywaniu szeregu wynalazków technicznych oraz zmian dokonanych w organizacji procesów pracy. Ikoną tej fazy była klasyczna fabryka, z wałem transmisyjnym - jako nieodłącznym jej atrybutem - aż do wynalezienia transformatora i jego zastosowania. Fabryka była wyposażona w sztywne linie technologiczne i maszyny, najpierw uniwersalne, a następnie specjalistyczne. Technologiami definiującymi były technologie przetwarzania ubytkowego materiałów w wyroby użytkowe (towary, wytwory), maszyny oraz technologie energetyczne. W procesie rozwoju tej fazy największe znaczenie miało wynalezienie maszyny parowej, zastosowanej także w górnictwie i przemyśle włókienniczym. Nowe maszyny wykorzystywane w produkcji musiały być wykonane z wytrzymałych materiałów konstrukcyjnych. Przełomowe okazało się zastąpienie węgla drzewnego koksem w hutnictwie. Pozwoliło to na rozwój różnych gałęzi przemysłu, w tym przemysłu maszyn i urządzeń. Rozwój przemysłu 
maszynowego zaowocował produkcją samochodów. W drugiej połowie XX w. rozwinęła się rewolucja naukowo-techniczna, dzięki czemu nastąpił niespotykany wcześniej transfer wiedzy i technologii do życia gospodarczego. Zmieniła się fabryka, zmieniła się też praca człowieka.

Początek drugiej rewolucji przypada na lata 70. XIX w. Największymi innowacjami, które wówczas zrewolucjonizowały i zdynamizowały przemysł, były dwa nowe źródła energii: elektryczność (silnik elektryczny) i silnik spalinowy. Rozpoczęła się era produkcji masowej, z zastosowaniem podziału pracy i rozdrobnieniem pracy, które doprowadzono do absurdu - praca podzielona i ściśle zunifikowana, produkcja replikacyjna towarów. Już w tej fazie rozwoju przemysłu pojawiły się zjawiska, które stały się osnową trzeciej rewolucji przemysłowej. Należy do nich upowszechnianie automatycznych maszyn i urządzeń technologicznych. Uzupełnione o sterowniki, stały się one zalążkiem trzeciej rewolucji przemysłowej, która rozpoczęła się pod koniec lat 60 . XX w. Wyzwoliło ją przemysłowe wykorzystanie sterowników programowalnych (1968), które otworzyło erę automatyzacji przemysłu opartego na zaawansowanej elektronice i technologiach informatycznych. Te zaś aktualnie są wszechobecne ${ }^{1}$.

Definicyjnie czwarta rewolucja przemysłowa - Przemysł 4.0/Industry 4.0 obejmuje technologie, które systemowo stosują: a) modelowanie cyberfizyczne (Systemy Cyberfizyczne), b) Internet Rzeczy, Internet Usług, c) możliwości przetwarzania chmurowego, d) Internet Wszechrzeczy (Furmanek, 2018a).

Technologiami wiodącymi są technologie wykorzystujące rozwiązania sztucznej inteligencji. Coraz liczniejsze grupy badaczy zaliczają powstające w oparciu o wymienione technologie inteligentne fabryki do zjawisk piątej rewolucji przemysłowej.

Pojawienie się nowych zjawisk w obrębie przemian cywilizacyjnych generuje pytanie o ich zakres oraz o znaczenie dla życia i pracy człowieka i jego wspólnot. Jednymi z najważniejszych w tym zakresie zjawisk są nowe technologie oraz nowe formy organizacji i instrumentalizacji pracy. Analizujemy je w kontekście technologii. Te z nich, które znajdują szerokie zastosowanie gospodarcze, angażują znaczące grupy ludzi, wywołują zmiany także poza nimi samymi, nazywa się technologiami kluczowymi. Jesteśmy świadkami zmian powodowanych przez

1 W 1968 r. inżynierowie amerykańskiego przemysłu samochodowego wyszli z inicjatywą wprowadzenia sterowania nowego typu, w którym algorytm działania miał być zapisywany nie w „odrutowaniu”, lecz w pamięci. W 1970 r. na wystawie obrabiarek w Chicago przedstawiono pierwszy system sterowania działający na zasadzie cyklicznego obiegu pamięci programu. W końcu 1973 r. oszacowano, że w USA w przemyśle obróbki metali było ponad 3000 sterowników. W 1977 r. Zakłady Automatyki Przemysłowej MERA ZAP w Ostrowie Wielkopolskim podjęły produkcję pierwszego w Polsce systemu sterowania programowalnego (sterownika PLC) o nazwie INTELSTER PC4K (w oparciu o licencję). 
coraz szersze zastosowanie wielu nowych technologii w naszym życiu (Furmanek, 2014a, s. 61 i n.). Bez wątpienia do takich technologii należą te, które oparte są na sztucznej inteligencji. Ich wielorakość użytkowania jest podstawą piątej rewolucji przemysłowej.

Wprowadzenie rozwiązań piątej rewolucji przemysłowej skutkuje wielorako. W życiu gospodarczym ujawnia się to w pojawieniu się nowych zawodów i specjalności zawodowych. W edukacji z kolei powstają nowe kierunki kształcenia na poziomie szkół średnich i studiów wyższych. Bez wątpienia należy do nich zaliczyć takie kierunki, jak: inżynieria materiałów, nauki o materiałach, mechatronika, robotyka itd. (za: Furmanek 2017, 2018a).

\section{POTRZEBA NOWEJ SZKOŁY}

Przemiany cywilizacyjne, które dokonują się powszechnie, w istocie rzeczy generują nowy model życia społecznego. Tworzące się społeczeństwo informacyjne budowane jest - zgodnie z paradygmatem aksjologicznym - na odmiennych niż społeczeństwa agrarne i industrialne kategoriach aksjologicznych. W miejsce środków produkcji, siły roboczej i kapitału wchodzą informacja, wiedza oraz kompetencje osobiste człowieka. Zmiana ta ma charakter radykalny. Oznacza to, że społeczeństwo informacyjne potrzebuje nowego modelu szkoły - szkoły budowanej na nowych założeniach aksjologicznych.

To wszystko, co dziedziczymy po społeczeństwie industrialnym (czyli szkołę odpowiadającą jego potrzebom i aspiracjom), nie może zadowalać i nie powinno pozostawać w strukturach organizacji oświaty społeczeństwa informacyjnego (Solarczyk-Ambrozik, 1999). Nie są możliwe do zaakceptowania tylko kosmetyczne działania na starym systemie edukacji. Uświadamiamy sobie, że konieczne jest wdrożenie odmiennego modelu szkoły polskiej (w tym szkoły zawodowej), odpowiadającego na obecne i przyszłe wyzwania cywilizacyjne.

Społeczeństwo informacyjne (nazywane społeczeństwem wiedzy, społeczeństwem poinformowanego rozumu) formułuje pod adresem edukacji swoje oczekiwania. Edukacja, która w istocie prowadzi do wykształcenia (w konwencji omawianych przemian cywilizacyjnych), powinna być obecnie rozumiana jako proces świadomego i zorganizowanego wykorzystywania informacji w celu przygotowania człowieka do posługiwania się informacją.

Model klasycznych rozwiązań edukacji zawodowej budowanej dla potrzeb społeczeństwa industrialnego jest już dziś dysfunkcjonalny, a zasady jego organizacji muszą być przeformułowane. Podstawową zasadę organizacji edukacji w społeczeństwie industrialnym można sformułować następująco: „Uczę się 20 lat, pracuję 40 lat, korzystając ze zdobytej wiedzy, a po tym spokojna emerytura". Treść tej zasady wymaga rozwinięcia. Po pierwsze, wskazuje ona na trwałość wiedzy zdobytej w ciągu długiego okresu kształcenia. Tymczasem zdajemy sobie 
sprawę, że wiedza bardzo szybko zmienia swoje oblicze, starzeje się, pojawia się nowa wiedza, a z nią - nowe technologie. Wymaga to systematycznego uczenia się w trakcie aktywności zawodowej. Po drugie, czas pracy również ulega zmianom, wyraźnie maleje jego długość w stosunku do lat życia człowieka.

Inne zasady edukacji w społeczeństwie industrialnym to: wiedza podstawowa, jednolita dla całego społeczeństwa; obowiązujący kanon wykształcenia ogólnego; wiedza zdobywana raz w ciągu życia zawodowego; edukacja finansowana przez społeczeństwo; uzupełniające kształcenie zawodowe finansowane w znaczącej części przez zakłady pracy (Furmanek, 2009). Jak wobec tych zasad modelować procesy edukacyjne, aby zachować prymat człowieka nad modelem organizacji społeczeństwa informacyjnego?

Filozofia obecnie realizowanej edukacji opiera się na tzw. strategii adaptacyjnej, zwanej także strategią transmisji kulturowej. Tymczasem w warunkach dynamicznie zmieniającej się pracy ludzkiej konieczne jest reorientowanie edukacji na strategię krytyczno-kreatywną.

Tabela 1. Podstawowe cechy edukacji w trzech modelach cywilizacji

\begin{tabular}{|c|c|c|c|}
\hline Cecha podstawowa & $\begin{array}{c}\text { Społeczeństwo } \\
\text { przedprzemysłowe }\end{array}$ & $\begin{array}{c}\text { Społeczeństwo } \\
\text { przemysłowe }\end{array}$ & $\begin{array}{c}\text { Społeczeństwo } \\
\text { informacyjne }\end{array}$ \\
\hline Język & łacina i greka & języki narodowe & angielski + inny język \\
\hline Uczniowie & dzieci elity & młodzi ludzie & każdy \\
\hline Wiek uczniów & 6-20 lat & 6-16 lat & w każdym wieku \\
\hline Kto płaci za naukę & rodzice & podatnik & uczeń \\
\hline Organizator & Kościół & państwo & korporacje \\
\hline Miejsce nauki & siedziby wiedzy & miasta & wszędzie \\
\hline Czas nauki & wzajemnie ustalony & ustalony & kiedykolwiek \\
\hline System ekonomiczny & gospodarka tradycyjna & tayloryzm & neoliberalizm \\
\hline $\begin{array}{c}\text { Źródło programów } \\
\text { nauczania }\end{array}$ & nauczyciel & państwo & potrzeby ucznia \\
\hline
\end{tabular}

Źródło: (Tiffin, Rajasingham, 1995).

Analiza ukazanych w tabeli 1 zjawisk pozwala sformułować kolejne wyzwanie dla edukacji, która dziś rozwija umiejętności, jak stosować wiedzę (uczy operatywności wiedzy), a jutro musi rozwijać kompetencje do tego, jak tworzyć wiedzę (kształcenie talentów). To zaś wymaga przejścia w filozofii edukacji od doktryny edukacji adaptacyjnej do doktryny edukacji kreatywnej. Konieczna i pilna zmiana filozofii, aksjologii i teleologii wychowania wymaga wyeksponowania wychowania ku wartościom. Należy wdrożyć nowe nurty dydaktyki kreatywnej na wszystkich etapach edukacji (por. Furmanek, 2009; Szymański, 2014). 


\section{PRZEMIANY W NAUKACH PEDAGOGICZNYCH}

Jaką rolę w tym względzie powinny wypełnić nauki pedagogiczne? Misją wszystkich nauk pedagogicznych jest takie wspomaganie rozwoju każdego człowieka, aby zapewnić mu jego optymalny wzrost i zabezpieczyć go przed wykluczeniem społecznym, kulturowym i cywilizacyjnym.

Aktualnie pedagogika weszła w obszar nowych problemów, które musi podjąć za cenę swego istnienia i własnej tożsamości. Sytuację tę kreuje coraz powszechniej akceptowany nowy humanistyczny paradygmat nauki. Jest on opozycyjny wobec pozytywizmu, scjentyzmu i technologizmu. Pomimo zróżnicowania i rozczłonkowania ma jednak wspólną wartość. Otóż eksponuje dotychczas redukowane wymiary człowieka. ,W jego centrum jest człowiek ze swoją personalistyczną, materialno-duchową specyfiką i złożonością, zarówno w swojej bytowo-ontologicznej indywidualności, jak epistemologiczno-poznawczej świadomości” (Ratajek, 1996, s. 33 i n.). Prymat człowieka oznacza przyjęcie homocentrycznego celu badań pedagogicznych.

Tabela 2. Podstawowe cechy modelu szkoły tradycyjnej i informacyjnej

\begin{tabular}{|c|c|c|}
\hline Cechy modelu & Model tradycyjny & Model informacyjny \\
\hline Teoria & $\begin{array}{c}\text { behawioryzm (nagrody i kary, } \\
\text { stopnie szkolne) }\end{array}$ & $\begin{array}{l}\text { psychologia poznawcza i humanistyczna } \\
\text { (wewnętrzne samozadowolenie) }\end{array}$ \\
\hline Metoda & podręcznik, wykład & wspólny projekt badawczy \\
\hline Umiejętności & $\begin{array}{l}\text { zapamiętywanie, prezentowanie } \\
\text { problemu, sprawozdanie }\end{array}$ & $\begin{array}{c}\text { komunikowanie, negocjowanie sposobów } \\
\text { rozwiązania problemów, prezentowanie } \\
\text { alternatywnych rozwiązań }\end{array}$ \\
\hline Rola ucznia & przyswajanie wiedzy & $\begin{array}{l}\text { uczeń jako badacz, sprawozdawca, } \\
\text { syntetyzator }\end{array}$ \\
\hline Rola nauczyciela & ekspert & nauczyciel jako uczeń \\
\hline Władza/autorytet & nauczyciel & nauczyciel, uczeń \\
\hline Ocena & nauczyciel & nauczyciel, uczeń \\
\hline $\begin{array}{l}\text { Środowisko } \\
\text { uczenia się }\end{array}$ & $\begin{array}{l}\text { współzawodnictwo, recytacja, } \\
\text { ocena myślenia uczniów przez } \\
\text { nauczyciela }\end{array}$ & $\begin{array}{l}\text { współpraca, spolegliwość grupowa, } \\
\text { uprawianie myślenia wyższego rzędu }\end{array}$ \\
\hline
\end{tabular}

Źródło: opracowanie własne.

Mariusz Dembiński (2015) zauważa za Sergiuszem Hessenem, że edukacja jest realizowana w obszarze życia społeczno-politycznego w wymiarze oświatowym i organizacyjnym. Edukacja funkcjonuje w konkretnej rzeczywistości społeczno-kulturowej; jest sprawą człowieka w świecie. W naszym przypadku przyjmujemy, że edukacja to pedagogika zorientowana praktycznie. Należy oddzielić ją od pedagogiki jako wiedzy humanistycznej, mającej na celu opis i badanie pro- 
wadzące do pełnego rozwoju osoby (ukształcanie, wykształcanie) (Dembiński, 2015). Pedagogika zorientowana teoretycznie to system wiedzy humanistycznej dotyczący zjawisk wynikających z działań prowadzonych w związku z realizacją zadań misji pedagogiki (Palka, 1998).

Jeżeli spojrzymy na wyzwania generowane przez zmiany zachodzące w cywilizacji z tych dwóch perspektyw, tj. pedagogiki zorientowanej praktycznie oraz pedagogiki zorientowanej teoretycznie, to wyraźnie dostrzeżemy siatkę problemów i wyzwań, przed jakimi staje współczesna pedagogika.

\section{PRZEMIANY W METODOLOGII BADAŃ WE WSPÓŁCZESNEJ PEDAGOGICE}

Zagubienie metodologiczne pedagogów jest konsekwencją zagubienia istoty człowieka. Wiąże się z tym bardzo ważne pytanie: Czy pedagogika jest nauką humanistyczną? Przedmiotem zainteresowań wszystkich dyscyplin humanistycznych (w tym pedagogicznych) jest człowiek. Konsekwencje tego stanowiska są wielorakie. Pierwszą z nich jest odmienne widzenie człowieka i uznanie tego, że niezaprzeczalnymi atrybutami osoby ludzkiej są: godność jako poczucie własnej wartości; samoświadomość wartości; jedyność (zwana też indywidualizmem lub jednorazowością); przeżywanie świata i swojego w nim istnienia, zwłaszcza w odniesieniu do wartości (egzystowania); otwartość podczas nieustającego procesu stawania się człowiekiem (dziejowość, zmienność w czasie, transgresja).

Złożoność tak widzianej problematyki badań stawia przed pedagogami wiele wyzwań metodologicznych. Poznanie humanistyczne różni się bowiem od poznania obecnego w naukach przyrodniczych. Uwzględnienie swoistości obiektu badań nauk pedagogicznych wymusza przechodzenie od metodologii addytywistycznej (a nawet holistycznej) do metodologii badań systemowych, z jej wielorakością propozycji strategii, modeli i metod.

Pedagogika wywodzi się z fenomenologicznych i personalistycznych koncepcji filozoficznych człowieka, lecz także z indywidualistycznych i humanistycznych teorii psychologicznych. Ich wspólnym celem jest ponowne odkrycie człowieka, jego możliwości rozwojowych i jego ciągle wielkich potencjalności transgresyjnych. Pedagogika podejmuje próby stworzenia człowiekowi szansy najpełniejszej samorealizacji na miarę tego, „co mu jest przez naturę »dane« $\mathrm{i}$ tego, co powinien ze sobą uczynić, wykonując »zadaną《 misję transgrersyjną" (Ratajek, 1996, s. 33).

\section{OBSZARY SZCZEGÓLNYCH PRZEMIAN W PEDAGOGICE}

Rozwój cywilizacji oraz osiągnięcia nauk o człowieku sprawiają, że pedagogika współczesna niezmiennie znajduje się w sytuacji tworzenia się. Uderza tutaj podobieństwo do procesów rozwoju człowieka. Ciągle na nowo staje się on coraz 
bardziej człowiekiem. Działalność naukowa, ale i praktyka pedagogiczna, która chce wspomagać człowieka, ukazuje ogrom potrzeb w zakresie dalszego rozwoju pedagogiki. W niniejszym opracowaniu kataloguję najważniejsze obszary badań, które pilnie wymagają penetracji przez pedagogów.

Najbardziej wyrazistymi zjawiskami są te dotyczące dysfunkcjonalności polskiej edukacji oraz szerzącego się analfabetyzmu cywilizacyjnego i kulturowego (w tym analfabetyzmu aksjologicznego). Nie mniej ważne są zagubienie polskiej edukacji zawodowej oraz brak systemu kształcenia i doskonalenia nauczycieli.

Budowa katalogu zagubionych czy zaniedbanych obszarów polskiej pedagogiki jest zadaniem trudnym. Zmiany zachodzące we współczesnej pedagogice mają charakter kompleksowy. Obejmują one m.in.:

- odejście od uniwersalnych założeń pedagogiki naukowej na rzecz alternatywnych koncepcji edukacyjnych, tworzonych w kontekście konkretnych potrzeb środowiska,

- odejście od koncepcji wychowania adaptacyjnego na rzecz wychowania wspierającego optymalny wielostronny rozwój dyspozycji tkwiących w jednostce,

- odejście od obowiązującego powszechnie jednolitego schematu organizacyjno-programowego na rzecz programów otwartych (w tym autorskich),

- odejście od uniwersalizmu i algorytmizacji norm dydaktycznych na rzecz twórczego dostosowania sposobów postępowania nauczyciela do indywidualnych sytuacji pedagogicznych,

- odejście od dominującej roli nauczyciela w procesie dydaktycznym na rzecz postawy wspierającej i wyzwalającej w uczniach wartości i potencjalne możliwości rozwoju,

- odejście od przekazywania wiedzy i kształtowania umiejętności przewidzianych ,z góry” na rzecz rozwijania w uczniach postawy podmiotowo-krytycznej, kontestującej i dyskursywnej,

- uznanie zasady wzajemnego „współtworzenia się” osób uczestniczących w procesie edukacyjnym w oparciu o wartości etyczne i humanistyczne, regulujące ich wzajemny kontakt interpersonalny,

- uczynienie z wolności i odpowiedzialności zasady fundamentalnej w konstruowaniu modelu każdej jednostki dydaktycznej i każdej formy działań wychowawczych,

- uznanie subiektywizmu jako naturalnej cechy i niezbywalnej wartości procesu wychowania (por. Ratajek, 1996; Furmanek, 1999).

\section{ZAKOŃCZENIE}

Proces transformacji gospodarczej jest skorelowany z procesem przemian społecznych. Sens cywilizacji informacyjnej i budowanego w niej modelu społeczeństwa informacyjnego wyraża się w przewartościowaniu systemu aksjolo- 
gicznego ludzi oraz uwypukleniu w nim znaczenia informacji, wiedzy i kompetencji ludzi. Stajemy zarazem i w tym miejscu wobec ogólnego problemu: O jakie informacje, wiedzę i kompetencje chodzi? Z jakich źródeł człowiek te informacje powinien czerpać? Czy potrafi to czynić i czy potrafi z nich zrobić godziwy użytek? Czy przez to samo jest przygotowany do współprzyczyniania się do dalszego rozwoju cywilizacji wiedzy i społeczeństwa poinformowanego rozumu?

Tak sformułowane pytania ukazują kolejne obszary zagubienia polskiej pedagogiki. Chociaż podejmuje się je w różnych badaniach, to nie ma możliwości wdrożenia ich wyników. Zagubienie polskich pedagogów ma rozmaite wymiary, dotyczy różnych zjawisk należących do przedmiotu badań pedagogiki. W kolejnym opracowaniu analizie zostaną poddane te z nich, które w najbardziej znaczącym zakresie rzutują na osiągnięcia nauk pedagogicznych.

\section{BIBLIOGRAFIA}

Bauman, Z. (1997). Ponowoczesność jako źródło cierpień. Warszawa: Wydawnictwo Sic!

Bogaj, A. (1999). Kulturowe i cywilizacyjne determinanty reformy kształcenia ogólnego. W: J. Gnitecki, J. Rutkowiak (red.), Pedagogika i edukacja wobec nadziei i zagrożeń wspótczesności. Materiały z III Ogólnopolskiego Zjazdu Pedagogicznego (s. 163-171). Radom: Polskie Towarzystwo Pedagogiczne, Wydawnictwo i Zakład Poligrafii Instytutu Technologii Eksploatacji.

Czapiński, J., Wojciszke, B. (1997). Pogoń za lisem. Społeczne zróżnicowanie i struktura postaw wobec prywatyzacji. W: J. Gardawski, L. Gilejko (red.), Między nadzieją i lękiem. Społeczne efekty prywatyzacji (s. 37-76). Warszawa: Szkoła Główna Handlowa.

Dembiński, M. (2015). Recenzja książki: Bogusław Śliwerski, „Edukacja (w) polityce. Polityka (w) edukacji: inspiracje do badań polityki oświatowej”. Oficyna Wydawnicza „Impuls”, Kraków 2015, ss. 675. Pedagogika Społeczna, 3(57), 253-267.

Furmanek, W. (1999). Antynaturalistyczny paradygmat badań pedagogicznych. W: J. Sowa, D. Pstrąg (red.), Pedagogika opiekuńcza wobec współczesnej orientacji filozoficznej i praktyki pedagogicznej (s. 64-79). Rzeszów: CDP.

Furmanek, W. (2009). Edukacja a przemiany cywilizacyjne. Rzeszów: Wydawnictwo URz.

Furmanek, W. (2012a). Model człowieka odniesieniem do opisu przedmiotu badań pedagogiki pracy. W: T. Lewowicki, J. Wilsz, I. Ziaziun, N. Nyczkało (red.), Kształcenie zawodowe: pedagogika i psychologia (s. 109-125). Częstochowa-Kijów: Wydawnictwo Akademii im. Jana Długosza w Częstochowie.

Furmanek, W. (2012b). Model człowieka paradygmatem nauk pedagogicznych. Edukacja-Technika-Informatyka. Rocznik Naukowy, 3(3), 25-42.

Furmanek, W. (2014a). Humanistyczna pedagogika pracy. Praca człowieka w cywilizacji informacyjnej. Rzeszów: Wydawnictwo URz.

Furmanek, W. (2014b). Humanistyczna pedagogika pracy. Współczesność obiektem badań. Rzeszów: Wydawnictwo URz. 
Furmanek, W. (2015). Humanistyczna pedagogika pracy. Sytuacje trudne w pracy czlowieka. Rzeszów: Wydawnictwo URz.

Furmanek, W. (2017). Piąta rewolucja przemysłowa. Eksplikacja pojęcia. Edukacja - Technika -Informatyka. Rocznik Naukowy, 2(24), 275-283, DOI: https://doi.org/10.15584/eti.2018.2.38.

Furmanek, W. (2018a). Najważniejsze idee czwartej rewolucji przemysłowej (Industrie 4.0). Dydaktyka Informatyki, (13), 55-63, DOI: https://doi.org/10.15584/di.2018.13.8.

Furmanek, W. (2018b). Model człowieka odniesieniem do opisu przedmiotu badań pedagogiki wartości. W: W. Furmanek A. Długosz (red.), Wartości w pedagogice. Uczenie się (s. 136-150). Rzeszów: Wydawnictwo URz.

Furmanek, W. (2019). Człowiek w badaniach pedagogiki zorientowanej personalistycznie. Rzeszów: Wydawnictwo URz.

Maryniarczyk, A., Stępień, K. (red.). (2003). Błąd antropologiczny. Lublin: Polskie Towarzystwo Tomasza z Akwinu.

Myoo, S., Hańderek, J. (red.). (2014). Filozofia technologii. Lublin: E-Naukowiec.

Palka, S. (red.). (1998). Orientacje w metodologii badań pedagogicznych. Kraków: Wydawnictwo UJ. Ratajek, Z. (1996). Dydaktyka wobec problemów współczesnej pedagogiki. Zeszyty Wszechnicy Świętokrzyskiej, (3), 19-33.

Solarczyk-Ambrozik, E. (1999). Zmiana społeczna jako wyzwanie dla kształcenia zawodowego. W: J. Gnitecki, J. Rutkowiak (red.), Pedagogika i edukacja wobec nadziei i zagrożeń wspótczesności. Materiały z III Ogólnopolskiego Zjazdu Pedagogicznego (s. 368-375). Radom: Polskie Towarzystwo Pedagogiczne, Wydawnictwo i Zakład Poligrafii Instytutu Technologii Eksploatacji.

Such, J. (1973). Wstęp do metodologii ogólnej nauk. Poznań: Wydawnictwo Naukowe UAM.

Sztompka, P. (2009). Socjologia zmian społecznych. Kraków: Znak.

Szymański, M.J. (2014). Edukacyjne problemy wspótczesności. Kraków: Oficyna Wydawnicza Impuls. Tiffin, J., Rajasingham, L. (1995). In Search of the Virtual Class. Education in an Information Society. London: Routledge.

Toffler, A. (2007). Szok przyszłości. Przeźmierowo: Wydawnictwo Kurpisz.

\section{SUMMARY}

Polish pedagogues seem to be lost in precisely formulating their own research problems. There are many reasons. The most important are: anthropological error, high dynamics of civilization changes, difficulties with interpretation and understanding of the phenomena of modern civilization of knowledge, new expectations for education, the need to reorient the research methodology. The author devoted considerable attention to the difficulties in identifying and understanding the directions of civilization changes, their dynamics, complexity and new quality. The article also indicates the most important areas of research that urgently require penetration by contemporary pedagogues.

Keywords: lost; civilization; knowledge society; education 